\title{
Effects of Environmental Factors on Growth Performance of Kilis goat in Gaziantep province
}

\author{
Sabri Güll ${ }^{1, *}\left(\mathbb{D}\right.$, Mahmut Keskin ${ }^{1}\left(\mathbb{D}\right.$, Şerafettin Kaya ${ }^{1}$ (D) \\ ${ }^{1}$ Hatay Mustafa Kemal University, Agricultural Faculty, Department of Animal Science, Antakya, Hatay, Türkiye \\ *Corresponding Author
}

\section{Article History}

Received: 17 November 2021

Accepted: 24 December 2021

First Online: 01 April 2022

\section{Corresponding Author*}

Tel.: +905335490697

E-mail: sabrigul@gmail.com

\section{Keywords}

Kilis goat

Environmental factors

Growth performance

\begin{abstract}
The study aimed to investigate the effects of maternal age, birth type, gender, birth month and birth season on birth weight, weaning weight and average daily gain of Kilis goat kids reared in Gaziantep province. This study evaluated a total of 14956 kids born in 2019 and 2020 participating in the national project named "Improvement of Kilis Goat under Farm Conditions". The result showed an average birth weight of $3.5 \pm 0.01$ $\mathrm{kg}$, a weaning weight of $15.2 \pm 0.02 \mathrm{~kg}$ and an average daily gain of $193.4 \mathrm{~g}$. Maternal age, sex, the month of birth, and year also affected mean birth weight, weaning weight, and daily gain $(P<0.01)$.
\end{abstract}

\section{Introduction}

For sustainable production in livestock, the factors affecting the growth and development of the offspring should be determined appropriately. One of the ways to increase the effectiveness of selection on quantitative traits is to identify the effects of measurable environmental factors that influence yields. Thus, using these values, corrections can be made to the production values of individuals. This standardization of yield values eliminates the effects of the environmental factors in question and more accurately identifies the animals to be selected as breeding stock. The most important discrete environmental factors are maternal age, birth type, and sex. It is known that old mothers grow faster than young ones, single borns are faster than twins and male lambs grow faster than females (Akbaş et al., 2013; Gül et al., 2016; Çoban and Torun, 2020; Keskin et al., 2017; Nuntapaitoon et al., 2021). Therefore, the birth and weaning weights of the above animals may be higher. The genes that control the sex and birth type of the offspring and the genes that control growth and development are different. Therefore, if the growth and development characteristics of the animals to be selected for breeding are taken into account, eliminating the impact of environmental factors with the corrections to be made will increase the accuracy of the selection. The meat, milk, leather and hair of sheep and goats are finding increasing use in different parts of life. For this reason, the breeding of small livestock is well on the way to finding the place it deserves, as its value is increasing day by day. Domestic goats, like other breeding goats, have characteristics such as better digestibility of cellulosic feeds, resistance to disease, ability to move freely in all types of terrain conditions, and economic efficiency under extensive conditions.

Kilis goat, which is one of the local genetic resources, is also an important genetic source for our country. Moreover, it is the breed with the highest milk yield among domestic goat breeds. In order to breed Kilis goats, in 2011, the Ministry of Agriculture and Forestry, General Directorate of Agricultural Research and Policy, initiated the project of breeding Kilis goats in Gaziantep province, which is a sub-project of the National Project of Sheep Breeding in Public Ownership. Under this project, goat breeders learned to keep records and awareness was created. Within the scope of this project, the milk yield, birth weight and 
weaning weight of goats are determined and the selection of breeding animals is based on these data.

In animal production, the object is to increase the number of possible animals that will reach productive age and to obtain the highest yield from these animals under the breeding conditions. For this reason, birth and weaning weights are very important, and birth weight is one of the most important characteristics that determine survival. At the same time, it will be of great benefit for breeding to know the influence of the factors affecting these traits in future studies.

In this study, the effects of environmental factors on goat cub growth and development were evaluated based on the data from this project.

\section{Materials and Methods}

In this study, birth and weaning weights of Kilis goat kids born in 2019 and 2020 were used in the project named Breeding of Kilis Goats in Gaziantep. A detailed description of the data structure with the sample size was presented in Table 1.

Table 1. Descriptive statistics of growth traits in Kilis goat kids.

\begin{tabular}{llll}
\hline Traits & BW & WW & ADG \\
\hline No. of observation & 14956 & 13983 & 13983 \\
Mean & 3.5 & 15.2 & 193.4 \\
Standard deviation & 0.52 & 1.81 & 28.07 \\
Standard error & 0.01 & 0.02 & 0.23 \\
Coefficient of Variation & 0.14 & 0.12 & 0.15 \\
Minimum & 1.60 & 9.85 & 101.7 \\
Maximum & 6.48 & 24.50 & 333.3 \\
\hline
\end{tabular}

$\overline{\text { BW: Birth weight, WW: Weaning weight, ADG: Average daily weight }}$

The goats were grazed in the surrounding pastures throughout the year, depending on the season. The pastures are generally covered with short seasonal grasses and shrubs. Depending on the production season and variety, they are grazed on stubble after harvesting barley, wheat and chickpeas. During severe winter periods and when grazing is insufficient, supplementary feeding of barley, bran, wheat cracked, lentil, barley and wheat straw mixtures were given in the amount of $400-600$ g per animal.

In the study, the birth weight and weaning weight of newborn kids were weighed using digital scales with a sensitivity of $100 \mathrm{~g}$ precision balance. Date of birth, type of delivery, sex and weaning weight ( $60^{\text {th }}$ day) was also recorded. Birth and weaning weights were evaluated using an additive correction coefficient for sex, birth, month of birth, year of birth and maternal age.
The mathematical model of study is;

$Y_{i j k l m}=\mu+\alpha_{i}+\beta_{j}+\gamma_{k}+f_{l}+e_{i j k l m}$, in this model,

$\mathrm{Y}_{\mathrm{ijklm}}$, is an individual observation

$\mu$, the overall mean

$\alpha_{i}$, i. effect of the sex (female or male),

$\beta_{\mathrm{j}}$, j. effect of the birth type (single, twin, triplet),

$\gamma_{k}, k$. effect of the birth month (Jan., Feb., March)

$f_{l}$, I. effect of the maternal age $(1,2,3,4,5 \geq$ age),

$e_{i j k l m}$, is the experimental error.

Statistical analyzes of the study were performed using the General Linear Model (GLM) and it's significance control of differences between group means by Duncan multiple comparison test in Statistical Package for Social Sciences version 21.0 software for Windows. The normality assumption was tested with Kolmogorov-Smirnov and Shapiro-Wilk tests. The homogeneity assumption was tested with Levene's test. Explanatory statistics of variables are given as mean \pm standard error (SPSS, 2012).

\section{Results and Discussion}

In this study, the effects of maternal age, the month of birth, year of birth, type of delivery and sex on birth and weaning weights of Kilis goat kids were investigated (Table 2).

Table 2 shows that sex has an effect on birth weight. Birth weights of both sexes were close $(3.6+0.01 \mathrm{~kg}$ vs. $3.5+0.01 \mathrm{~kg})$, but these differences were statistically significant $(P<0.01)$. The influence of sex in kids was also evident in weaning weight. Again, similar results were obtained and the numerical difference between them was statistically significant $(P<0.01)$. A similar effect was also observed in daily body weight gain $(P<$ 0.01 ). there were similar effects in favour of males in terms of developmental traits.

Several researchers have found that sex has an effect on birth, weaning, and daily weight gain. (Savaş, 2009; Andries, 2013; Deribe and Taye, 2013; Gül et al., 2016; Keskin et al., 2017, Çelik and Oflaz, 2018). The birth weight of Kilis goats is $3.8 \mathrm{~kg}$ in male kids and 3.4 $\mathrm{kg}$ in female kids; weaning weight is $11.9 \mathrm{~kg}$ in females and $12.6 \mathrm{~kg}$ in males. Özdemir and Keskin (2018), reported that the birth weights of Kilis goat kids $3.4 \mathrm{~kg}$ in females and $3.8 \mathrm{~kg}$ in males and weaning weights of $12.6 \mathrm{~kg}$ and $13.5 \mathrm{~kg}$ according to the same sex order in Kilis goat kids reared in Gaziantep. Our results were close to the researchers' reports in terms of birth weight and higher than their reports in terms of weaning weight. This difference could be due to differences in care, feeding and herds.

It was determined that the type of delivery has an effect on birth weight. While birth weights of single and twin kids were similar, numerical differences were important between triplets and the other two types of birth $(P<0.01)$. On the other hand, the single and twin kids had similar body weights at weaning $(P>0.05)$. There were significant differences between triplet and the others $(P<0.01)$. The highest weaning weight was recorded by the single kids $(15.2 \pm 0.02 \mathrm{~kg})$ and the 
Table 2. The least-square means \pm SE of the growth performance in Kilis goat kids by the gender, birth type and mother age.

\begin{tabular}{lcccccc}
\hline & $\mathbf{n}$ & BW (kg) & $\mathbf{n}$ & $\mathbf{W W ~ ( k g )}$ & $\mathbf{n}$ & ADG (g) \\
\hline Gender & & & & & & \\
Male & 7475 & $3.6 \pm 0.01$ & 7009 & $15.2 \pm 0.02$ & 7009 & $194.3 \pm 0.34$ \\
Female & 7481 & $3.5 \pm 0.01$ & 6974 & $15.1 \pm 0.02$ & 6974 & $192.4 \pm 0.32$ \\
$\mathbf{P}$ & & 0.000 & & 0.000 & & 0.000 \\
Birth type & & & & & & \\
Single & 8972 & $3.6 \pm 0.01^{\mathrm{b}}$ & 8262 & $15.2 \pm 0.02^{\mathrm{b}}$ & 8262 & $193.6 \pm 0.32^{\mathrm{b}}$ \\
Twin & 5963 & $3.5 \pm 0.01^{\mathrm{b}}$ & 5700 & $15.1 \pm 0.02^{\mathrm{b}}$ & 5700 & $193.0 \pm 0.33^{\mathrm{b}}$ \\
Triplet & 21 & $3.1 \pm 0.01^{\mathrm{a}}$ & 21 & $14.3 \pm 0.22^{\mathrm{a}}$ & 21 & $186.5 \pm 0.75^{\mathrm{a}}$ \\
$\mathbf{P}$ & & 0.000 & & 0.000 & & 0.028 \\
Maternal age & & & & & & \\
2 & 2569 & $3.5 \pm 0.01^{\mathrm{a}}$ & 2420 & $14.7 \pm 0.04^{\mathrm{a}}$ & 2420 & $187.2 \pm 0.56^{\mathrm{a}}$ \\
3 & 3124 & $3.6 \pm 0.01^{\mathrm{b}}$ & 2898 & $15.2 \pm 0.03^{\mathrm{b}}$ & 2898 & $193.3 \pm 0.52^{\mathrm{b}}$ \\
4 & 3628 & $3.5 \pm 0.01^{\mathrm{a}}$ & 3316 & $15.1 \pm 0.03^{\mathrm{b}}$ & 3316 & $193.3 \pm 0.47^{\mathrm{b}}$ \\
$5 \geq$ & 5635 & $3.6 \pm 0.01^{\mathrm{b}}$ & 5349 & $15.4 \pm 0.03^{\mathrm{c}}$ & 5349 & $196.2 \pm 0.39^{\mathrm{c}}$ \\
$\mathbf{P}$ & & 0.000 & & 0.000 & & 0.000 \\
Overall & 14956 & $3.5 \pm 0.01$ & 13983 & $15.2 \pm 0.02$ & 13983 & $193.4 \pm 0.24$ \\
\hline BW: Birth weight WW:Weaning weight ADG: Average daily gain & & &
\end{tabular}

BW: Birth weight, WW: Weaning weight, ADG: Average daily gain

Table 3. The least-square means \pm se of the growth performance in Kilis goat kids by the months and years.

\begin{tabular}{lcccccc}
\hline Months & $\mathbf{n}$ & $\mathbf{B W ~ ( k g )}$ & $\mathbf{n}$ & $\mathbf{W W ~ ( k g )}$ & $\mathbf{n}$ & ADG (g) \\
\hline January & 4653 & $3.5 \pm 0.01^{\mathrm{a}}$ & 4385 & $15.2 \pm 0.03^{\mathrm{b}}$ & 4385 & $194.5 \pm 0.42^{\mathrm{b}}$ \\
February & 7867 & $3.5 \pm 0.01^{\mathrm{a}}$ & 7384 & $15.1 \pm 0.02^{\mathrm{a}}$ & 7384 & $193.2 \pm 0.34^{\mathrm{ab}}$ \\
March & 2436 & $3.6 \pm 0.01^{\mathrm{b}}$ & 2214 & $15.1 \pm 0.03^{\mathrm{a}}$ & 2214 & $191.5 \pm 0.55^{\mathrm{a}}$ \\
$\mathbf{P}$ & & 0.000 & & 0.037 & & 0.000 \\
Years & & & & & & \\
2019 & 7330 & $3.5 \pm 0.01$ & 6752 & $14.5 \pm 0.02$ & 6752 & $188.7 \pm 0.33$ \\
2020 & 7626 & $3.6 \pm 0.01$ & 7231 & $15.5 \pm 0.02$ & 7231 & $197.7 \pm 0.33$ \\
$\mathbf{P}$ & & 0.000 & & 0.000 & & 0.000
\end{tabular}

BW: birth weight, WW: weaning weight, ADG: Average daily gain

lowest by the triplets $(14.3 \pm 0.22 \mathrm{~kg})$. This similarity was also the case with daily weight gain. While the live weights calculated for single and twin kids were similar (193.6 \pm 0.32 g vs. $193.0 \pm 0.33 \mathrm{~g}$ ), a statistical difference was found between these two groups and the triplet kids $(186.5 \pm 0.75 \mathrm{~g})$.

Studies on different goat breeds have determined the effect of birth type on birth weight, weaning weight and daily body weight gain (Momani et al., 2012; Deribe and Taye, 2013; Keskin et al., 2016; Özdemir and Keskin, 2018; Kurtay, 2019; Çoban and Torun, 2020). Gül et al. (2016) reported that the birth weight of Kilis goat kids was $3.0 \pm 0.05 \mathrm{~kg}$ for single kids in the control group, $2.5 \pm 0.06 \mathrm{~kg}$ for twins, $3.5 \pm 0.05 \mathrm{~kg}$ for single-born kids in the supplementary feed group, $2.9 \pm 0.08 \mathrm{~kg}$ in twin born kids, $2.9 \pm 0.08 \mathrm{~kg}$ in twin born kids. Weaning weights in Kilis goats were $16.0 \pm 0.14 \mathrm{~kg}$ and $14.1 \pm$ $0.23 \mathrm{~kg}$ in the control group according to the same birth type order while in the supplementary feeding group they were $17.7 \pm 0.29 \mathrm{~kg}$ and $16.1 \pm 0.22 \mathrm{~kg}$. The results were high concerning birth weight and low concerning weaning weight. The numerical differences between the goats maybe since the goats are kept in different provinces, as well as the differences in care and feeding. 
This study shows that maternal ages have effects on birth weights in different age groups. The birth weight of kids born to does age two years and kids born to does age 4 years were the same $(3.5 \pm 0.01 \mathrm{~kg} ; P>0.01)$, and the same situation was found in kids born to mothers aged 3 and 5 years and above $(3.6 \pm 0.01 \mathrm{~kg} ; P>0.01)$. The difference of $100 \mathrm{~g}$ between both age groups was statistically significant $(P<0.01)$. Dams have influences on weaning weight and daily weight gains. While the lowest weaning weight was obtained by the 2 years old mothers $(14.7 \pm 0.04 \mathrm{~kg})$, the highest value was obtained by the dams that had given birth at the age of 5 years and older $(P<0.01)$. As for daily live weight gain, the lowest kid weight was obtained by 2 -year-old mothers and the highest value was obtained by mothers who had given birth at the age of 5 years and above $(P<0.01)$.

In terms of birth weight and developmental characteristics of goats, Bolcalı and Küçük (2012) determined that maternal age was not significant in Saanen goats, on the other hand, some researchers reported that this factor has a significant effect on birth and weaning weights (Çelik and Oflaz, 2018, Mellado et al., 2006; Sghaier et al., 2007; Erten and Yılmaz, 2013).

The birth weights of kids were influenced by their birth months (Table 3). While weights of kids born in January and February were the same $(3.5 \pm 0.01 \mathrm{~kg}$ vs. $3.5 \pm 0.01$ $\mathrm{kg})$, this value was $3.6 \pm 0.01 \mathrm{~kg}$ in March $(P<0.01)$.

Weaning weight and daily weight gain were also affected by birth months $(P<0.05 ; P<0.001)$. Daily live weight gain was $194.5 \pm 0.42 \mathrm{~g}$ in kids born in January, $193.2 \pm 0.34 \mathrm{~g}$ in kids born in February and $191.5 \pm 0.55$ $\mathrm{g}$ for kids born in March $(P<0.01)$.

This situation, which may vary according to the region and pasture vegetation may have a positive or negative effect on the developmental characteristics of the kids with high birth weight in the current study. We know that the fact that goats give birth at different months affects the birth weight, weaning weight and daily gain of kids. Thus, Browning et al. (2011) found that the average birth weight of goats were $2.95 \mathrm{~kg}$ in March and $3.17 \mathrm{~kg}$ in May. In the same study, the average weaning weights and daily weight gains were informed as $15.58 \mathrm{~kg}$ and $139.8 \mathrm{~g}$ for March and $13.19 \mathrm{~kg}$ and $111.1 \mathrm{~g}$ for May, respectively. It has also been reported that birth months affect birth weight, weaning weight and daily gain in kids (Andries, 2013; Das et al., 2018; Alemu et al., 2020; Nuntapaitoon et al., 2021). The reports of these researchers are in line with our results. Years of birth have important effects on the birth weight, weaning weight and daily weight gain (Table 3 ). There are different studies that years have important or unimportant effects on these characteristics. Thus, they were found that year of birth did not affect the developmental characteristics of kids in Kilis goats (Bolcalı and Küçük, 2012; Gül et al., 2016). However, Savaş (2009), Petrovic et al. (2012), Andries (2013), Das et al. (2018), Alemu et al. (2020), Nuntapaitoon et al. (2021) found that the year has got effect on these characteristics. In the present study, it can be speculated that the effect of the year on these characteristics were caused by semi-extensive production systems in goat breeding. The fact that production is largely dependent on natural pasture and the climatic conditions can change from year to year undoubtedly affect these results.

\section{Conclusion}

The current results show that maternal age, birth month, birth year, sex and birth type have significant effects on birth weight, weaning weight and daily live weight gain in Kilis goats. The results indicate that eliminating the effects of these environmental factors will increase the efficiency of selection to select the breeding stocks for Kilis goat herds.

\section{Author Contributions}

All authors contributed equally to the study.

\section{Conflicts of Interest}

The author declares no conflicts of interest.

\section{Acknowledgments}

The authors would like to thank the Republic of Türkiye Ministry of Agriculture and Forestry, General Directorate of Agricultural Research and Policies for its project support (Project No: 27KLS2012-01).

\section{References}

Akbas, A.A., Colak, M., Elmaz, O., Saatci, M. (2013). Determination of growth performance of the Saanen kids reared in north-west Mediterranean condition. Eurasian J Vet Sci. 29, 2: 70-75.

Alemu, T.T, Ashebir, W., Aman, G., Mieso, G., Genet, D. (2020). Growth performance evaluation of goat breed under farmers management at Fantale district, Oromia regional state, Ethiopia. SF Journal of Agricultural and Crop Management 1, 2: 1-5.

Andries, K.M. (2013). Growth and performance of meat goat kids from two seasons of birth in Kentucky. Sheep \& Goat Research Journal 28: 16-20.

Bolacalı, M., Küçük, M. (2012). Fertility and milk production characteristics of Saanen goats raised in Muş region. Kafkas Univ Vet Fak Derg. 18, 3: 351-358.

Browning, R.Jr., Leite-Browning, M.L. (2011). Birth to weaning kid traits from a complete diallel of Boer, Kiko, and Spanish meat goat breeds semi-intensively managed on humid subtropical pasture. Journal Anim Sci 89, 9: 2696-2707.

Çelik, H.T., Oflaz, M. (2018). Investigation on survival rate and growth characteristics of pure Hair goat and Saanen $x$ Hair goat $\left(F_{1}, B_{1}, B_{2}\right)$ crossbreds in breeder conditions. Mediterranean Agricultural Sciences 31, 1: 77-85.

Çoban, Y., Torun, O. (2020). Çukurova Üniversitesi Ziraat Fakültesi Araştirma ve Uygulama Çiftliğinde 
yetiştirilen keçilerin döl ve süt verim performanslari. Ç.Ü Fen ve Mühendislik Bilimleri Dergisi 39, 10: 91-99.

Das, B.C., Bera, S., Pandit, S., Panda, R., Roy, M. (2018). Studies on growth parameters of black Bengal goats in coastal Sundarban of West Bengal. International Journal of Fauna and Biological Studies 5, 1-4.

Deribe, B., Taye, M. (2013). Evaluation of growth performance of Abergele goats under traditional management systems in Sekota district, Ethiopia. Pakistan Journal of Biological Sciences 16, 14: 692-696.

Erten, Ö., Yılmaz, O. (2013). Ekstansif koşullarda yetiştirilen Kıl keçilerinin döl ve süt verimi özelliklerinin araştırılması. YYU Veteriner Fakultesi Dergisi 24, 3: 109-112.

Gül, S., Keskin, M., Göçmez, Z., Gündüz, Z. (2016). Effects of supplemental feeding on performance of Kilis goats kept on pasture condition. Italian Journal of Animal Science 15, 1: 110-115.

Keskin, M., Gül, S., Can, E., Gündüz, Z. (2016). Yarı entansif koşullarda yetiştirilen Şam Keçileri ile Kilis $x$ Kıl keçisi melez genotipinin süt ve döl verim özellikleri. Lalahan Hay Araşt Enst Derg. 56, 1: 20-24.

Keskin, M., Gül, S., Biçer, O., Daşkıran, İ. (2017). Some reproductive, lactation, and kid growth characteristics of Kilis goats under semiintensive conditions. Turkish Journal of Veterinary and Animal Sciences 41: 248254.

Kurtay, T. (2019). Yetiştirici koşullarinda Halep Keçisi x Kilis Keçisi $F_{1}$ oğlaklarinin büyüme ve yaşama özelliklerinin belirlenmesi. Yüksek Lisans Bitirme Tezi. Dicle Üniversitesi Fen Bilimleri Enstitüsü, Diyarbakır, 54s.

Mellado, M., Valdez, R., García, J.E., López, R., Rodríguez, A. (2006). Factors affecting the reproductive performance of goats under intensive conditions in a hot arid environment. Small Rumin Res. 63: 110118.

Momani, MS., Sanogo, S., Coulibaly, D., Al-Olofi, S., Alkhewani, T. (2012). Growth performance and milk yield in Sahelian $x$ Anglo-Nubian goats following crossbreeding in the semi-arid zone of Mali. Agricultura Tropica Et Subtropica 45, 3: 117-125.

Nuntapaitoon, M., Buranakarl, C., Thammacharoen, S., Katoh, K. (2021). Growth performance of Black Bengal, Saanen, and their crossbred $F_{1}$ as affected by sex, litter size, and season of kidding Anim. Sci. J. 92: e13571.

Özdemir, F.H., Keskin, M. (2018). Comparison of Kilis goats raised in Gaziantep and Kilis provinces due to some morphological and physiological characteristics. Journal of Agricultural Faculty of Mustafa Kemal University 23, 1: 115-123.

Petrovic, C.V., Ilic, Z., Muslic, D.R., Petrovic, M.P., Petrovic, M.M., Tomic, Z., Marinkov, G. (2012). Analysis of environmental and genetic factors in growth characteristics of Balkan goat. Biotechnology in Animal Husbandry 28, 2: 275-282.

Savaş, T. (2009). Keçilerde doğum ağırlığı üzerine doğum tipi $x$ cinsiyet etkileşimi ve akrabalı yetişmenin etkisi. Tarım Bilimleri Dergisi 15, 1: 96-104.

Sghaier, N., Amor, G., Mabrouk, O, Mouldi, A., Mohamed, B.H. (2007). Indigenous kids weight variation with respect to non genetic factors under pastoral mode in Tunisian arid region. Journal of Animal Veterinary Advances 6, 3: 441-450.

SPSS (2012). IBM Corp. Released 2012. IBM SPSS Statistics for Windows, Version 21.0. Armonk, NY, USA: IBM Corp. 